\title{
On the processes of renewal of the North Atlantic deep water in the Irminger Sea
}

\author{
F. HolzKamm*, G. Krause†, and G. Siedler $\dagger$
}

(Received 1 September 1964)

\begin{abstract}
Observations of temperature and electrical conductivity by a recording in situ salinometer are discussed in respect to the physical processes connected with the renewal of North Atlantic deep water. The measured fine structure of the layering suggests that the downward movement of cooled surface water is combined with horizontal mixing down to more than $1000 \mathrm{~m}$ depth. This is confirmed by the existence of water elements which have slightly different temperature and salinity. Curves of temperature, conductivity, and salinity and T-S diagrams are shown.
\end{abstract}

IN RESPECT to the renewal of deep oceanic water, the Irminger Sea and the Labrador Sea play an outstanding role in the circulation of the Atlantic Ocean. The main features of the deep reaching vertical convection by surface cooling in winter were suggested by NANSEN (1912) and were proved by the following investigations : Meteor in 1935 (Wüst 1936, Wattenberg 1938, Dietrich 1957a), Anton Dohrn and Gauss during the "Polar Front Survey" in the IGY 1958 (DIETRICH 1957b, 1961, 1964, KoOpManN 1959), and Anton Dohrn and Aegir in 1961 (DieTrich, Stefansson 1961). These regions are therefore the places where deep convection can be studied. Two methods are applicable :

1. To record the fine structure of the vertical distribution of temperature and salinity with high accuracy.

2. To study the variations in time of this fine structure.

Two kinds of investigation had been reported before the measurements described in this article. JOSEPH $(1959 \mathrm{a}, \mathrm{b})$ showed some examples of the complicated thermal fine structure in the Irminger Sea recorded by thermocouples, and KRAUSs (1959a, b) described observations of temperature and salinity on a $36 \mathrm{hr}$ permanent station and showed the existence of internal waves in that region.

When the ICNAF-Expedition Norwestlant 2 was planned and the participation of Anton Dohrn on a cruise in the region southeast of Greenland in May and June 1963 was arranged, it was decided to use a recording in situ salinometer for the purpose of studying the processes of renewal of deep oceanic water. This was possible as ship time was made available for this special investigation. The instruments used consisted of a bathysonde (HINKELMANN 1956, 1957, 1958, KROEBeL 1961, Siedler 1963, Hinkelmann, Ihme 1963, Kroebel, Wick 1963) and a double function XY-recorder. The only difference from the method described in DeepSea Research (SIEDLER 1963) was the fact that an improved housing of the conductivity

*Deutsches Hydrographisches Institut, Hamburg, Germany.

†Institut für Meereskunde, Kiel University, Germany. 
probe was used which showed no noticeable pressure effect, and that the range magnifier was omitted because of the great variations of temperature to be found in the Irminger Sea.

Figure 1 shows the positions of the stations to be discussed. As it is not practicable to examine all the measurements made on the cruise during the time between 29 May 1963 and 17 June 1963, we shall deal only with four typical stations south-east of Cape Farewell. Figures 3 and 4 show the distribution of electrical

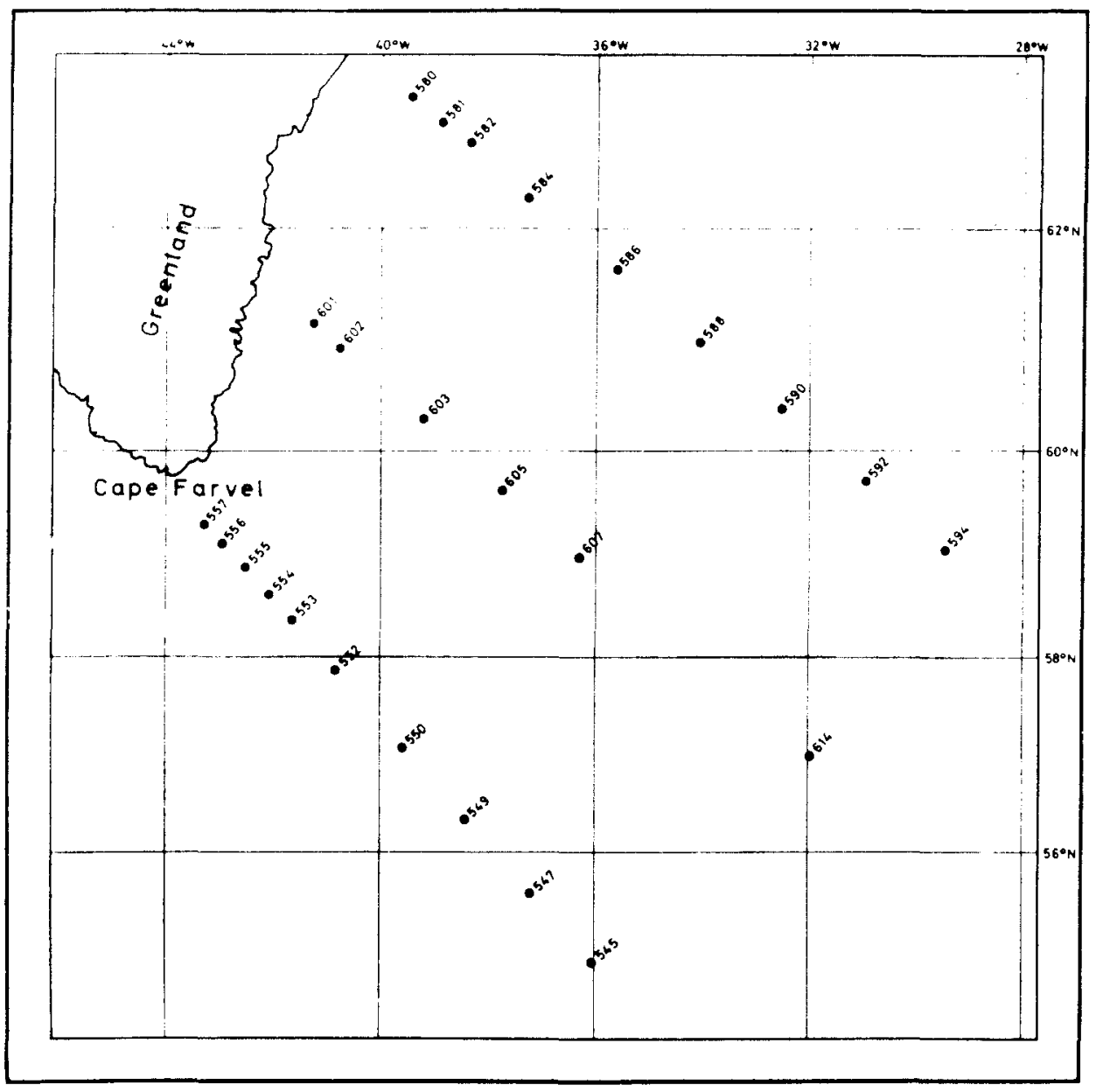

Fig. 1. Positions of the stations.

conductivity, salinity and temperature from stations 555 to 552 . Temperature and conductiyity were measured directly and the salinity was calculated for $40-60$ typical points of each curve. The following data were used: The dependence of electrical conductivity on chlorinity and temperature (THOMAs, THOMPSON, UTTERBACK 1934), the dependence of chlorinity on salinity (KNUDSEN 1901) and the tentative data of BradsHaw (1963) on the dependence of conductivity on pressure. The influence of $\mathrm{pH}$ and $\mathrm{CO}_{2}$ on conductivity were not taken into consideration. 
As the range-magnifier was not used on this cruise, the precision of measurement at a single station was less than that which the bathysonde normally achieves. In this work, the precision is better than $\pm 0.015^{\circ} \mathrm{C}, \pm 0.02 .10^{-3} \Omega^{-1} \mathrm{~cm}^{-1}$ and $\pm 0.030 \%$; the accuracy of the values in absolute terms also depends on the accuracy of the tables used.

The continuous lines were received while lowering the bathysonde, the dashed line represents the temperature distribution during raising. Great differences are to be found when comparing the temperature during lowering and raising of the instrument. The duration of the whole measurement was $40-60$ minutes, so a certain difference of temperature at a depth of e.g. $700 \mathrm{~m}$ represents the variation in a time interval of 30 minutes, if the whole measurement was carried out within 60 minutes to a maximum depth of $1400 \mathrm{~m}$. It is remarkable that great variations occur even in a depth of $1000 \mathrm{~m}$ although there are only intervals of about 10-20 minutes between lowering and raising the instrument. It should be emphasized that these differences are not simulated by the hysteresis of the depth meter, as we may be sure that the error by hysteresis is less than $5 \mathrm{~m}$ with this instrument. The temperature differences are confirmed by the points representing measurements obtained from Nansen bottles with attached reversing thermometers which were carried out about one hour latter. Mostly there is a significant difference between the temperatures given by the bathysonde and those given by reversing thermometers in those depths where great differences occur between the measurements during lowering and raising the in situ instrument. On the other hand there is a good agreement in those depths where small differences between lowering and raising exist. The surface measurements by mercury thermometers are not included.

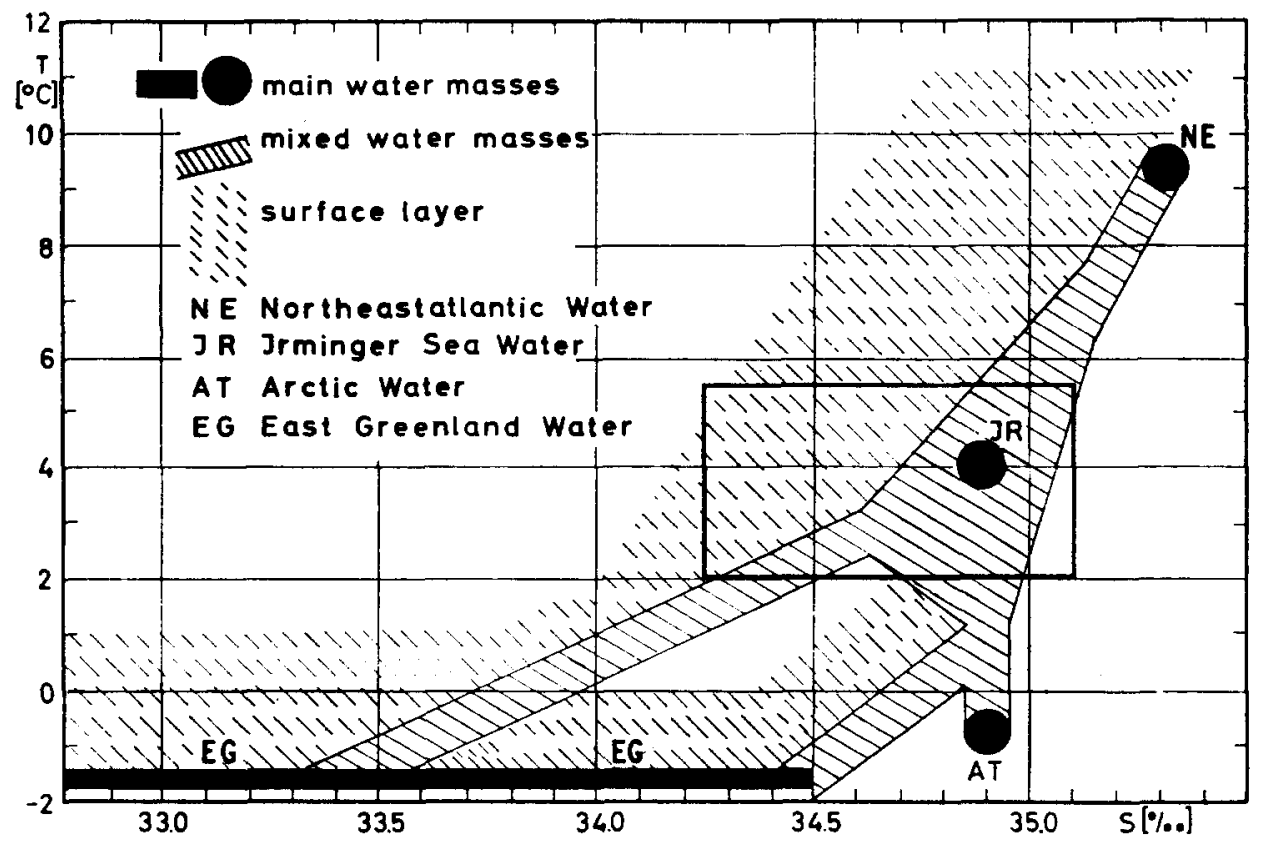

Fig. 2. T-S diagram of the water masses in the Irminger Sea (after G. DieTRICH, 1957). 


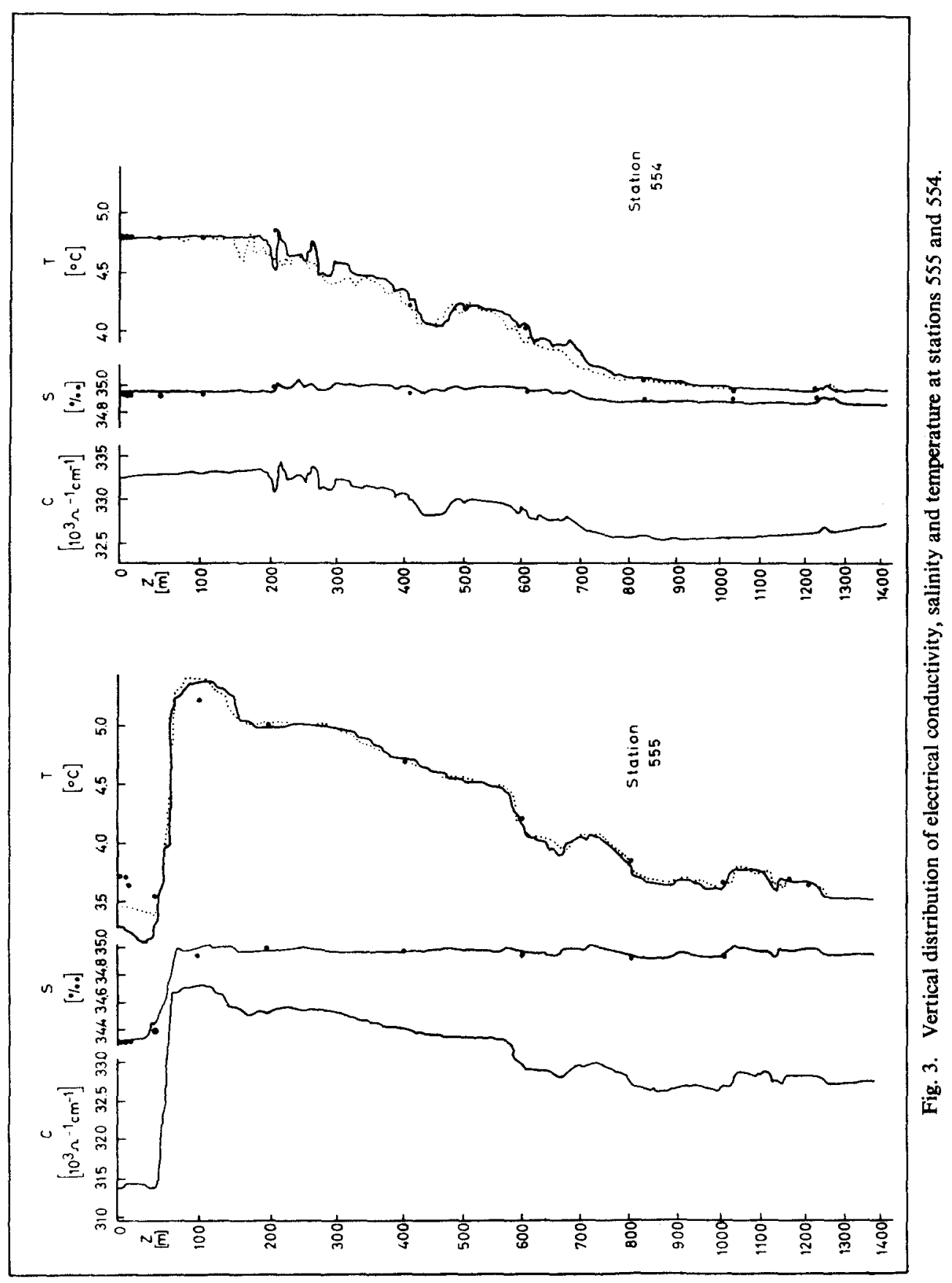




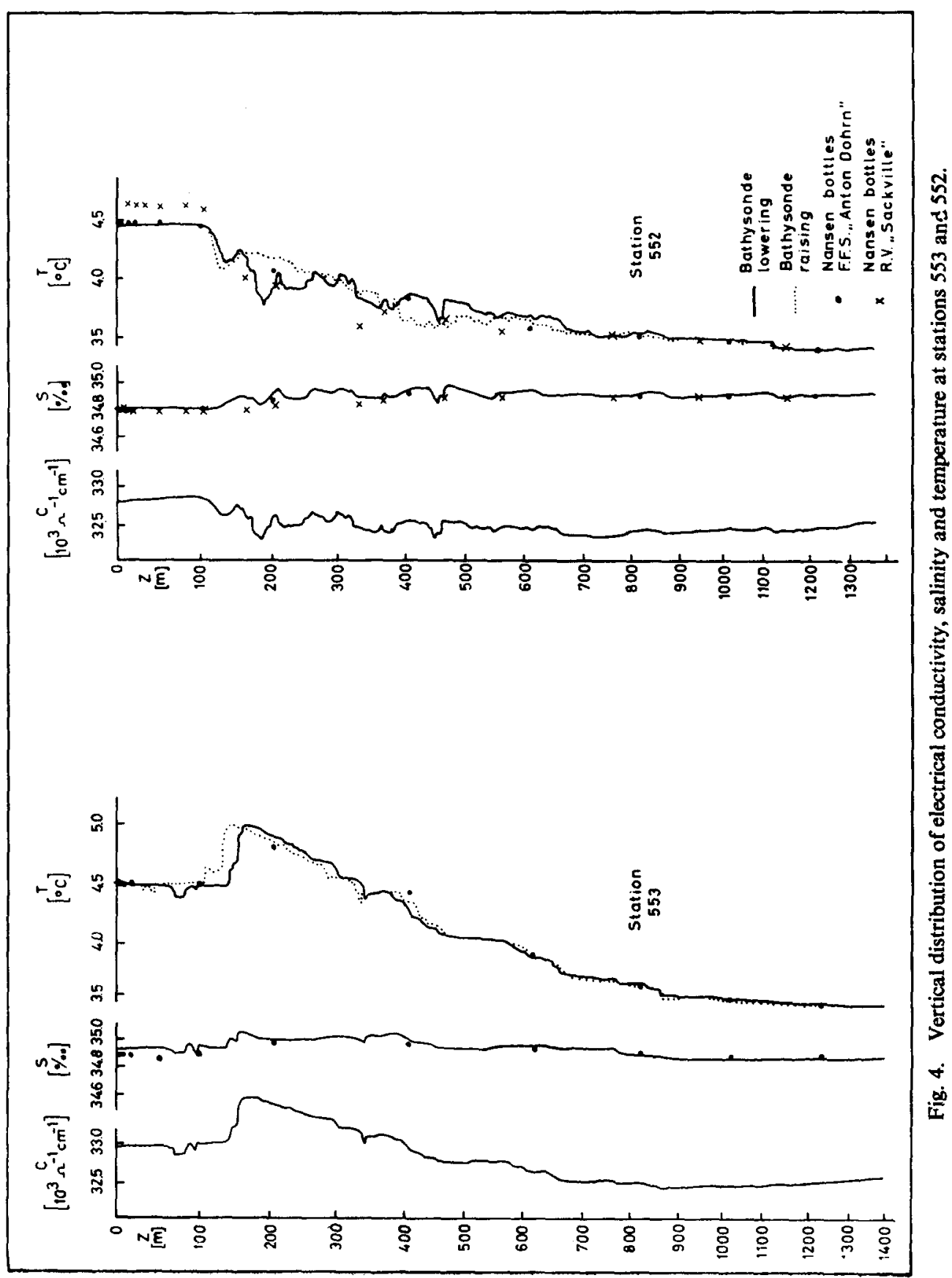




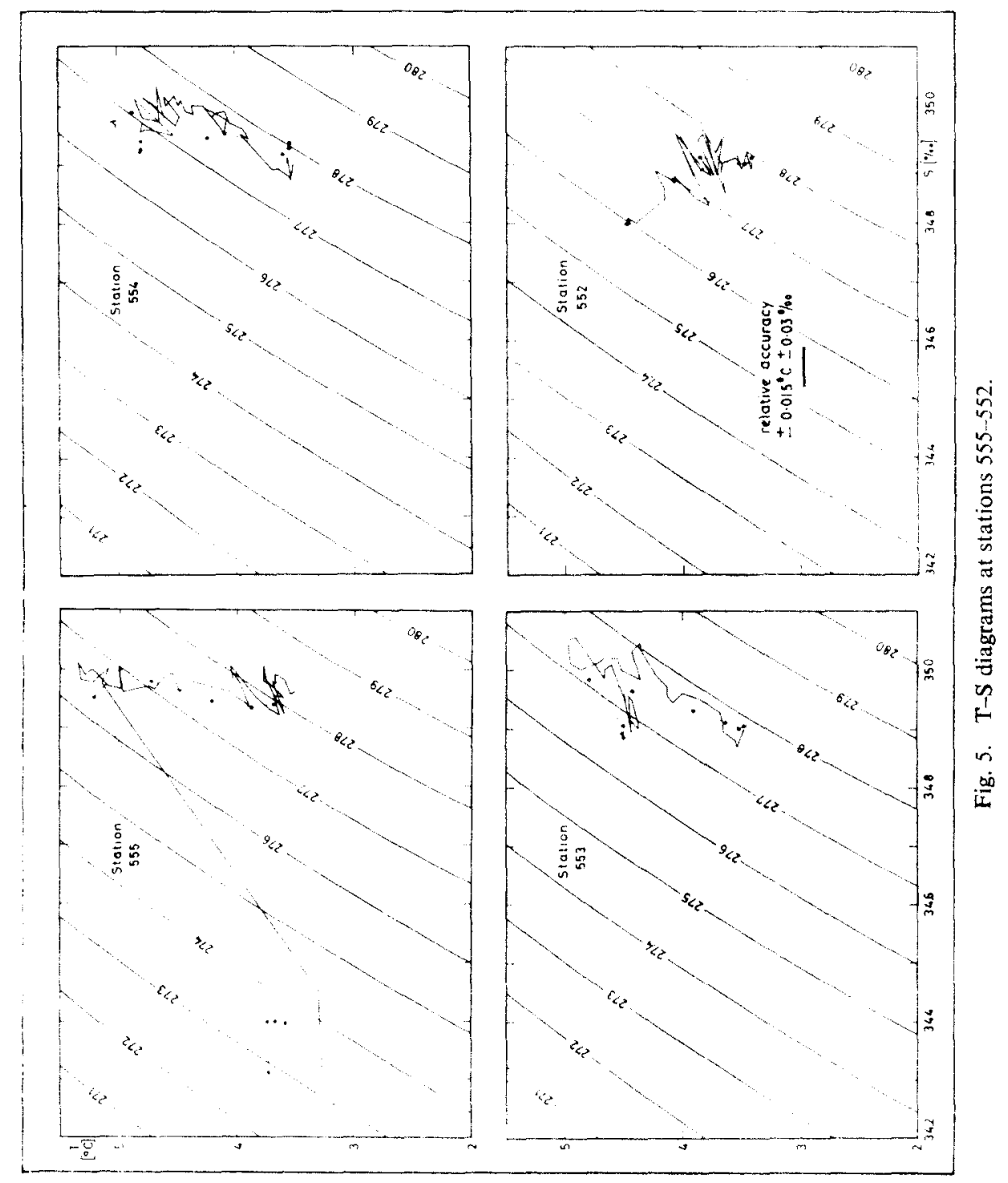




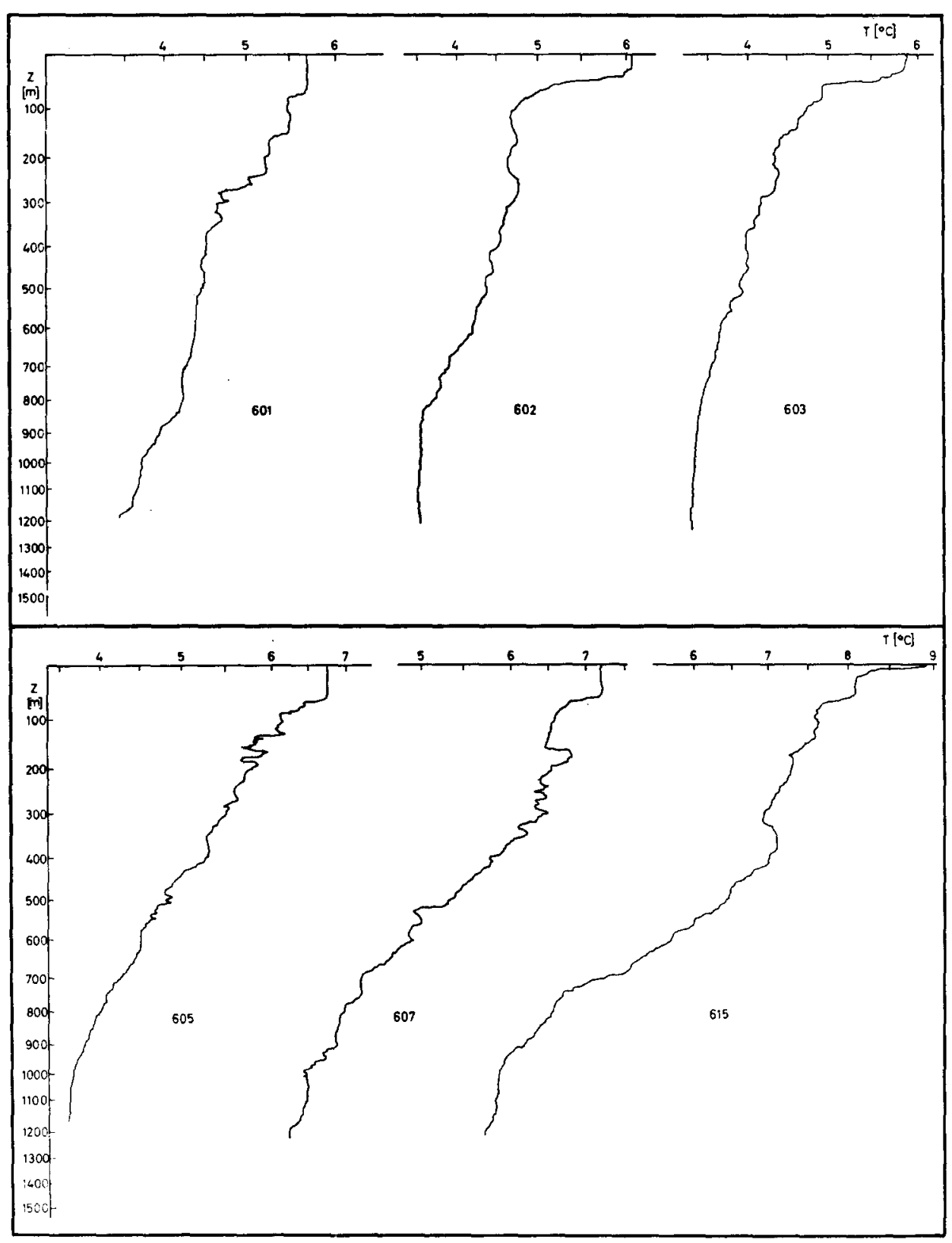

Fig. 6. Vertical distribution of temperature at stations 601-615. 
The conductivity shows first of all the influence of changing temperature, but the calculated salinity also shows a noticeable fine structure in this region even when allowance is made for the restricted accuracy. Values obtained from Nansen bottles represent averages of a certain water column during a certain time interval, because of the ship's motion, so that fine structures are not clearly shown. However, it is interesting to note than the Nansen bottle measurements showed these differences at station 552 where a parallel cast at nearly the same position was carried out by the Canadian ship Sackville at nearly the same time. (Distance between the two ships : about 1 nautical mile. Time of measurement : bathysonde 7.15 to 8.00 ; Nansen bottles Anton Dohrn : 8.45, Nansen bottles Sackville: 9.35). This station also showed remarkable differences in temperature and in salinity at those depths where differences occurred between lowering and raising of the bathysonde. We cannot state, according to these measurements, whether the differences are caused mainly by variations in time or in space, as the positioning of the two ships cannot be accurately determined. Nevertheless, it is clear from these findings that an intercalibration of methods should be carried out in the laboratory and not at sea.

A study of the T-S diagrams helps to explain the significance of the fine structure, when the water masses of the Irminger Sea are considered. Figure 5 shows the T-S diagrams for the four stations representing the measurements of the bathysonde, when lowered, and the Nansen bottles. The rectangle in the diagram of station 552 shows the precision of the bathysonde measurement. DIETRICH (1957b) has drawn a T-S diagram showing the general distribution of water masses in the Irminger Sea. Figure 2 shows the locations of the graphs of Fig. 5 in such a general diagram. We learn from this that with the exception of station 555 all the water represents typical Irminger Sea Water, whereas at the station nearest to Cape Farewell a mixture of Polar Water from the East Greenland Current and Irminger Sea Water occurs in the surface layer.

It is interesting to note that although we mostly find good agreement between the Nansen bottles and the bathysonde at comparable depths, nevertheless in the T-S curve of the bathysonde measurement deviations sometimes occur which roughly parallel the density lines and exceed the "square of accuracy." This could be explained by layers of slightly different water masses superimposing each other (COOPER 1961). But the great differences between the records during lowering and raising the instrument indicate that these deviations represent elements of water masses of a different degree of mixing and cooling with restricted extensions vertically as well as horizontally. It is indicated by the variations in space and in time that the simple concept of steadily sinking cooled surface water is not sufficient to explain the fine structure. It is suggested that a sinking of cooled surface water is combined with a mainly horizontal mixing of elements of water slightly different in temperature as well as in salinity, even in great depths. These two types of turbulent movement are superimposed on the oscillatory movement caused by internal waves. Such a structure should produce local density inversions, but the measurements were not precise enough to show this. Additional measurements of the vertical density gradients, using the full sensitivity of the instruments, would be needed to establish whether such instabilities occur.

To give an impression of the complicated fine structure, including the great 


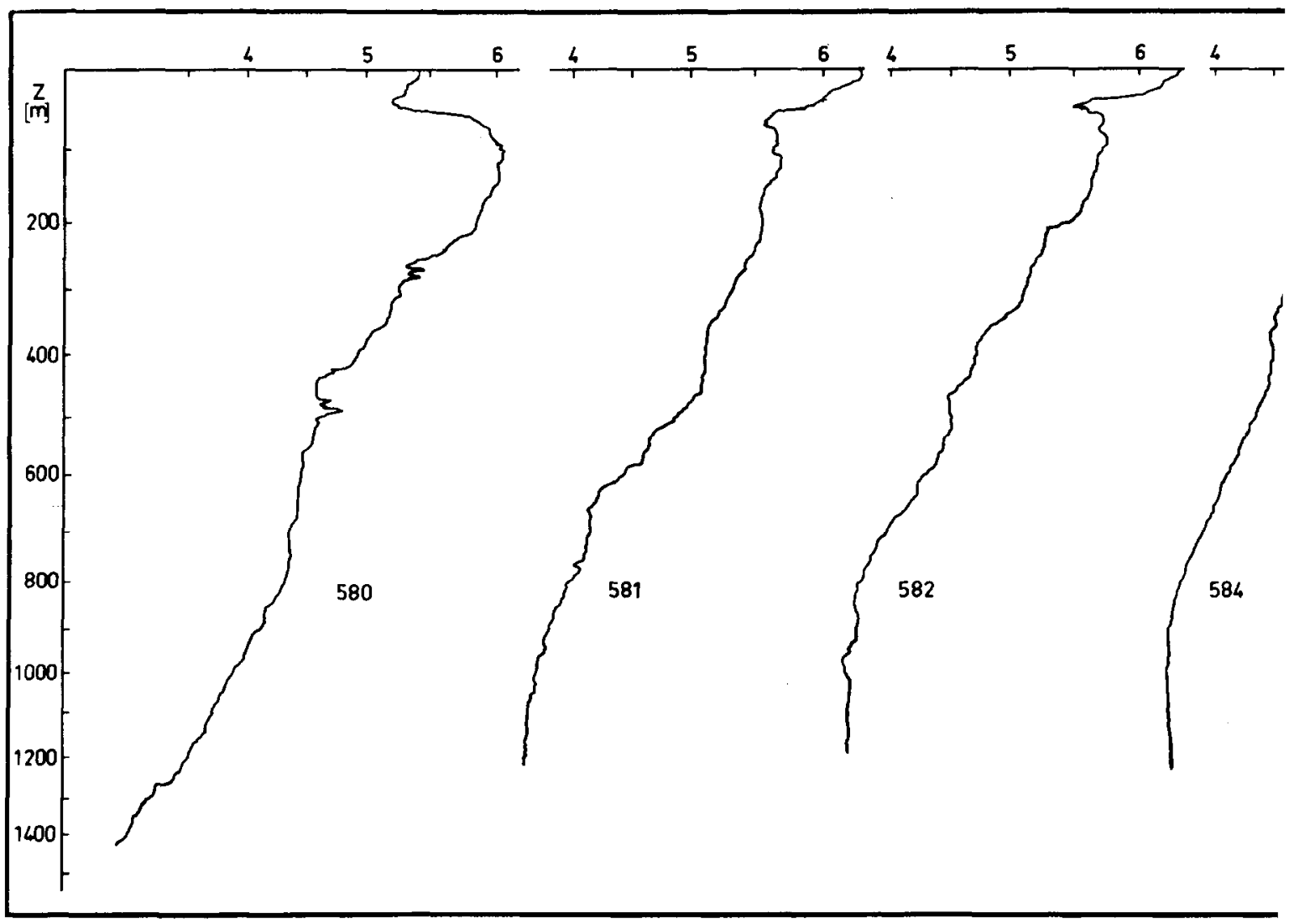

Fig. 7. Vert

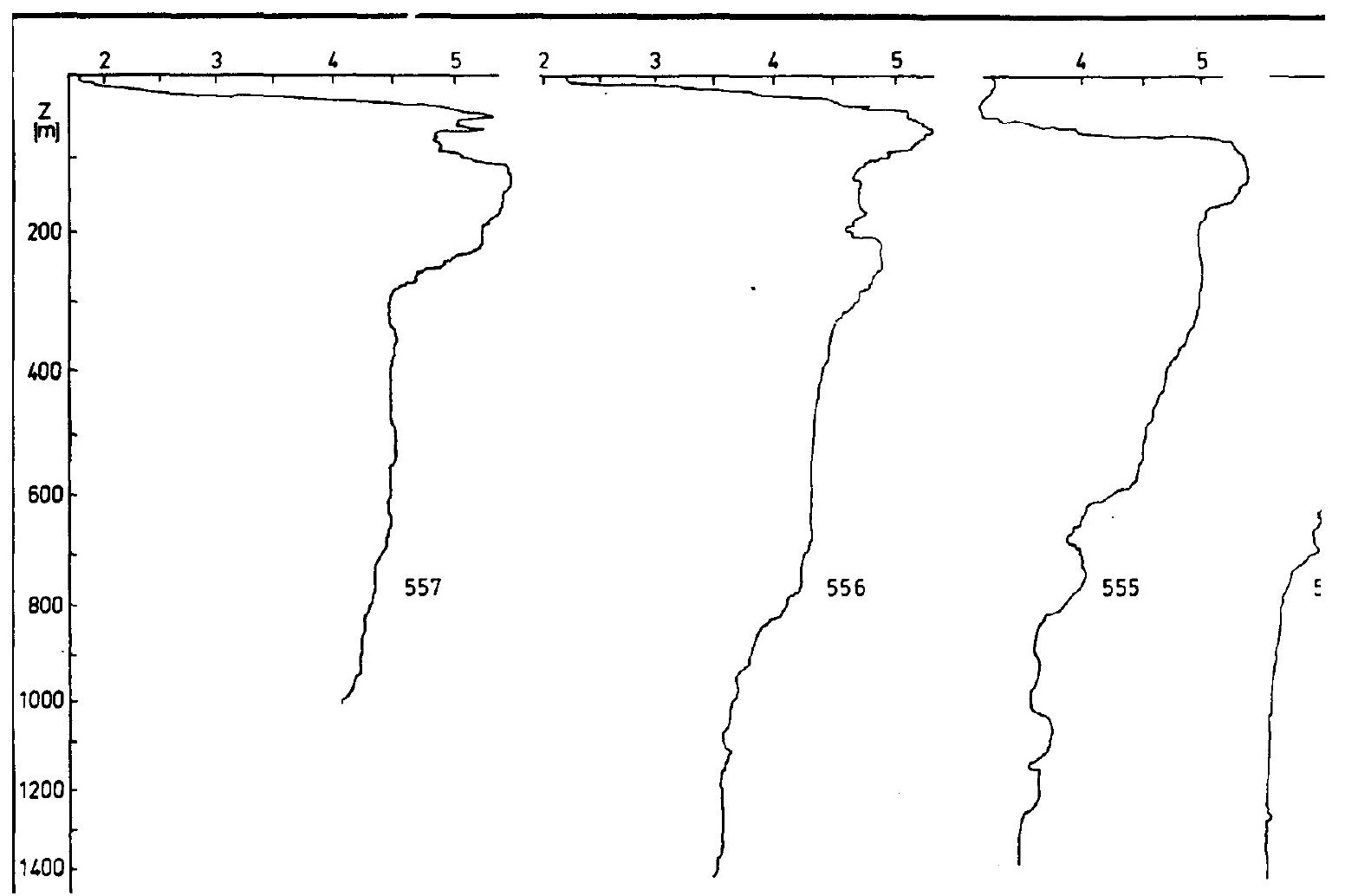




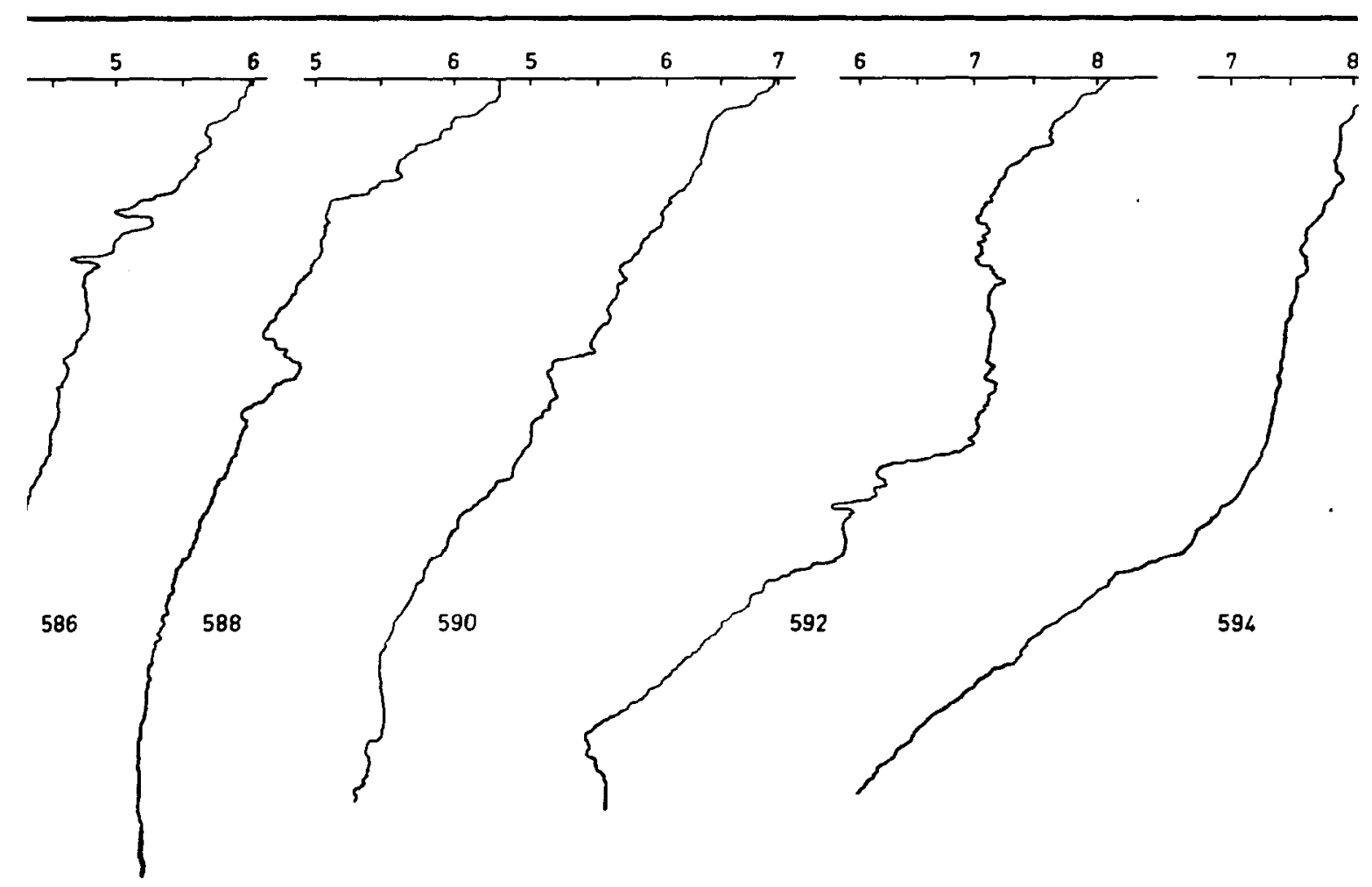

ature at stations 580-594.

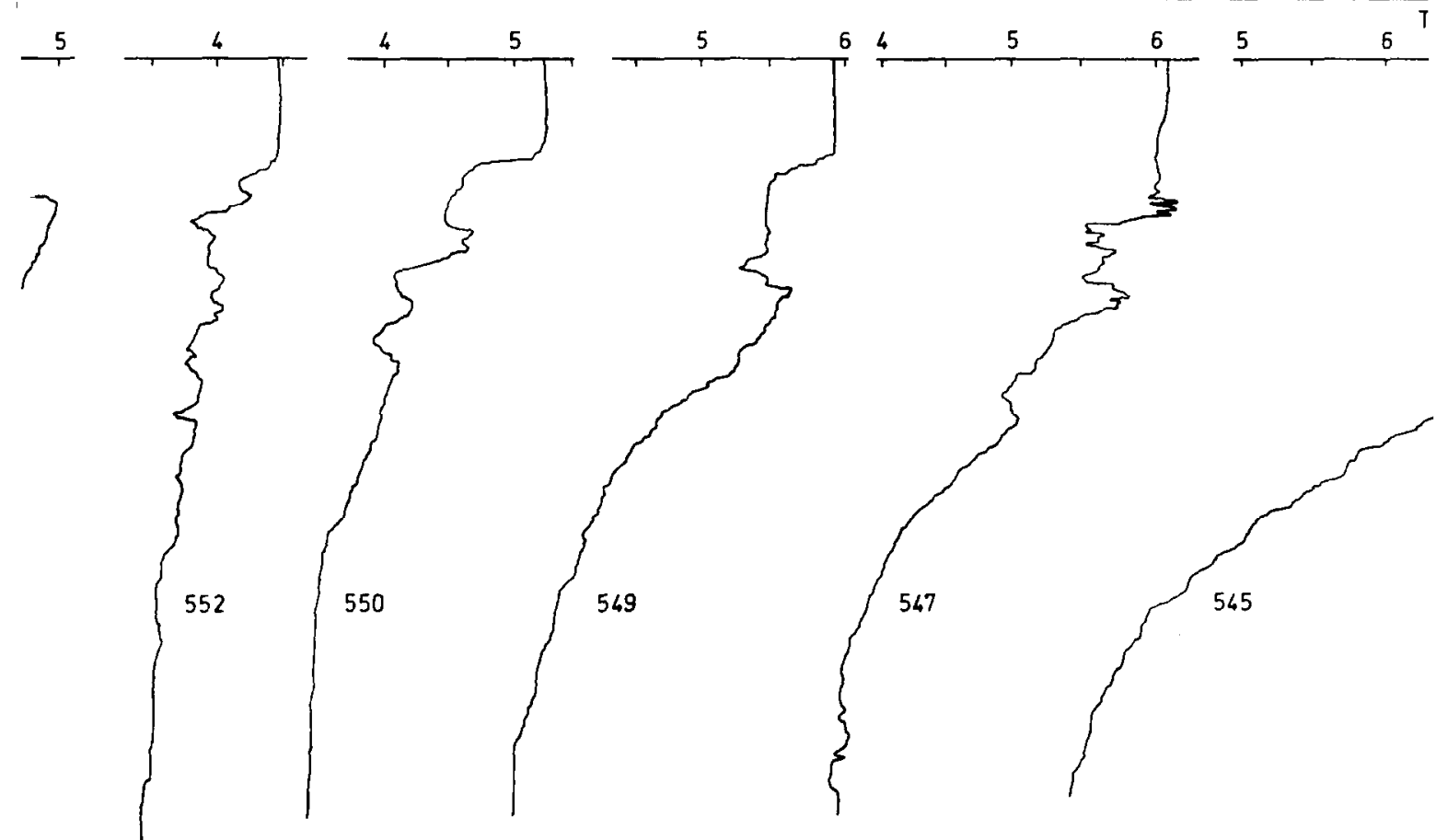


depths of the entire area investigated, one temperature record for each station is shown in Figs. 6-8. We find distributions of temperature indicating the East Greenland Current and the mixing of this polar water with the typical Irminger Sea water at some stations near the Greenland coast, especially those near Cape Farewell, whereas the influence of the Northeast Atlantic water is apparent mainly at the stations to the east. It should be added that the differences between the measurements during lowering and raising are often in the same order of magnitude as at stations 552 and 553. No attempt was made to draw isotherms because the distribution varies so much from one station to the next, that it is impossible to show the fine structure by such a graph.

In conclusion, the following results concerning the Irminger Sea can be stated :

1. The fine structure shown by our records in the distribution of temperature and salinity proves that small diverse bodies of differently cooled and mixed water exist down to below $1000 \mathrm{~m}$.

2. Combining this finding with what is already known of the renewal of North Atlantic deep water, we suggest that sinking of the surface water is combined, even at great depths, with horizontal mixing of elements of water which differ slightly in temperature and salinity.

\section{REFERENCES}

Bradshaw A. L. (1963) Unpublished tentative results about the effect of pressure on conductivity.

Canadian Oceanographic Data Centre (1963) ICNAF Provisional Data of R.V. Sackville $\mathbf{S} 72$.

COOPER L. N. H. (1961) Vertical and horizontal movements in the ocean. Oceanography, Amer. Assoc. Adv. Sci., Publ. No. 67 599-621.

DiETrich G. (1957a) Ozeanographische Probleme der deutschen Forschungsfahrten im Internationalen Geophysikalischen Jahr 1957/58. Dtsch. Hydrogr. Zeitschr. 10 (2), $39-61$.

DieTrich G. (1957b) Schichtung und Zirkulation der Irminger See im Juni 1955. Ber. Disch. Wiss. Komm. Meeresforsch., 14 (4), 255-312.

DIETRICH G. (1961) Some thoughts on the working-up of the observations made during the "Polar Front Survey" in the IGY 1958. Rapp. et Proc.-Verb., Cons. Perm. Int. Expl., Mer, 149, 103-110.

Dietrich G. and Stefansson U. (1961) Hydrographic conditions in the northern North Atlantic in April/May 1961. Ann. Biol., Cons. Int. Explor. Mer. 18, 18-23.

Dietrich G. (1964) Oceanic Polar Front Survey in the North Atlantic. Research in Geophysics, Cambridge Mass. (in press).

HinkelmanN H. (1956) Ein Gerät zur Schnellregistrierung des Druckes, der Temperatur und des Salzgehaltes für Anwendungen in der Ozeanographie. Kieler Meeresf. 12 (2), 200-201.

HinkelmanN H. (1957) Gerät zur Schnellregistrierung in der Ozeanographie. Z. angew. Physik, 9 (10), 500-513.

HINKRLMANN H. (1958) Ein Verfahren zur elektrodenlosen Messung der elektrischen Leitfähigkeit von Elektrolyten. $Z$. angew. Physik, 10 (11), 500-503.

HinkelmanN H. und IHME H. M. (1963) Ein elektrisches Tiefseethermometer mit kurzer Einstellzeit $Z$. angew. Physik, 15 (5), 429-435.

JosePH J. (1959a) Die Trübungsverhältnisse in der Irminger See im Juni 1955 und ihre hydrographischen Ursachen. Ber. Dtsch. Wiss. Komm. Meeresforsch. 15 (3), 238-259.

JosePH J. (1959b) Über die vertikalen Temperatur- und Trübungsregistrierungen in einer $500 \mathrm{~m}$ mächtigen Deckschicht des nördlichen Nordatlantischen Ozeans. Dtsch. Hydrogr. Zeitschr., Ergänzungsheft Reihe B $\left(4^{\circ}\right)$, Nr. 3, 48-55.

KNUDSEN M. (1901) Hydrographical Tables. Copenhagen.

KoopmanN G. (1959) Thermohaline Schichtung im jahreszeitlichen Wechsel zwischen Kap Farvel und der Flämischen Kappe Dtsch. Hydrogr. Zeitschr., Ergänzungsheft B $\left(4^{\circ}\right)$, Nr. 3, 40-46. 
Krauss 'V. (1959a) Úber meteorologisch bedingte interne Wellen auf einer Dauerstation südwestlich Islands. Dtsch. Hydrogr. Zeitschr., Ergänzungsheft Reihe B (4º), Nr. 3. 55-58.

KRAUSS W. (1959b) Meteorologically forced internal waves in the region south-west of Iceland. Rapp. Cons. Explor. Mer, Cons. Perm. Int. Expl., Mer, 149, 89-92.

KroebeL W. (1961) Zur Messmethodik von ozeanographischen Sondenmessgeräten. Kieler Mecresf. 17 (1), 17-24.

KroebeL W. and WiCK J. (1963) Registrierungen in situ im Nordatlantik mit der Bathysonde und einer neuen Messgerät für Schallgeschwindigkeit im Meerwasser mit extrem hoher Genauigkeit. Kieler. Meeresf. 19 (2), 133-141.

NANSEN F. (1912) Das Bodenwasser und die Abkühlung des Meeres. Intern. Rev. ges. Hydrobiol. u. Hydrogr. 5 (1), 1-42.

SiEDLER G. (1963) On the in situ measurement of temperature and electrical conductivily of sea-water. Deep-Sea Res. 10, 269-277.

Thomas B. D., Thompson Th. G., and Utterback C. L. (1934) The electrical conductivity of sea water. J. du Cons., 9, 28-35.

WatTENBERG H. (1938) Die Verteilung des Sauerstoffs im Atlantischen Ozean. Wiss. Ergebn. Deutsch. Atlant. Exp. “ Meteor." 1925-27, 9 (1), Berlin.

Wüst G. (1936) Schichtung und Zirkulation des Atlantischen Ozeans, Die Stratosphäre. Wiss. Ergebn. Deutsch. Atlant. Exp. “ Meteor." 1925-27, 6 (1), Berlin. 